\title{
Secure Hash Algorithm-256
}

National Cancer Institute

\section{Source}

National Cancer Institute. Secure Hash Algorithm-256. NCI Thesaurus. Code C80226.

An algorithm for computing a condensed representation of a message or a data file that produces a 256-bit message digest. 